\title{
TELAAH STRATEGI PEMBELAJARAN MATEMATIKA PADA SEKOLAH ALAM PEKALONGAN
}

\section{STUDY ON MATHEMATICS LEARNING STRATEGY IN NATURAL SCHOOL PEKALONGAN}

\author{
Drajat Stiawan \\ IAIN Pekalogan \\ * Corresponding Author. Email: drajatstiawan@iainpekalongan.ac.id \\ Received: 25 Februari 2020; Revised: 24 Maret 2020; Accepted: 30 Maret 2020
}

\begin{abstract}
ABSTRAK
Sekolah alam adalah sekolah yang kegiatan pembelajarannya tidak hanya terpaku di dalam kelas, tetapi juga memanfaatkan alam sekitar atau lingkungan sebagai objek pembelajaran. Pembelajaran matematika pada sekolah alam dilakukan sebagai upaya untuk menumbuhkan jiwa siswa menjadi lebih kreatif dan mandiri. Penelitian yang dilakukan bertujuan untuk mendiskripsikan bagaimana pelaksanaan pembelajaran matematika di Sekolah alam Ma'had Islam Pekalongan. Informan adalah kepala sekolah, guru matematika kelas IV dan V sekolah alam SD Ma'had Islam. Teknik dalam pengumpulan data menggunakan observasi dan wawancara. Analisis datanya meliputi pengumpulan data, reduksi data, penyajian data dan penarikan kesimpulan. Hasil penelitian menunjukan bahwa pelaksanaan pembelajaran matematika di Sekolah alam SD Ma'had Islam dilakukan di dalam kelas dan di luar kelas. Ketika di dalam kelas menggunkan metode ceramah dan tanya jawab. Saat di luar kelas (out door) lebih banyak menggunakan metode pemberian tugas dan game (bermain) serta memanfaatan bahanbahan yang ada di Alam, guna memahamkan siswa sesuai dengan materi yang diajarkan oleh guru matematika.
\end{abstract}

Kata Kunci : Pembelajaran, Matematika, Sekolah Alam

\section{ABSTRACT}

A natural school is a school whose learning activities are not only fixed in the classroom, but also utilize the natural surroundings or the environment as objects of learning. Mathematics learning in natural schools is done as an effort to grow students' souls to be more creative and independent. The research carried out aims to describe how the implementation of mathematics learning in Pekalongan's Ma'had Islam School of Nature. The informants are the school principal, mathematics teacher grades IV and $V$ of the natural school Ma'had Islam elementary school. The technique in collecting data uses observation and interviews. Data analysis includes data collection, data reduction, data presentation and conclusion drawing. The results showed that the implementation of mathematics learning in the natural school of Ma'had Islam Elementary School was done in the classroom and outside the classroom. When in class use the lecture and question and answer method. When outside the classroom (out door) use more methods of giving assignments and games (playing) and utilizing materials available in Nature, in order to understand students according to the material taught by mathematics teachers.

Keyword: Learning, Mathematics, School of Nature

How to Cite: Stiawan, D. (2020). Telaah Strategi Pembelajaran Matematika pada Sekolah Alam Pekalogan. Histogram: Jurnal Pendidikan Matematika, 4(1), 93 - 103, doi: http://dx.doi.org/10.31100/histogram.v4i1.561

Permalink/DOI: http://dx.doi.org/10.31100/histogram.v4i1.561

Copyright $@$ 2020, THE AUTHOR (S). This article distributed under the CC-BY-SA-license. 


\section{Histogram: Jurnal Pendidikan Matematika, 4 (1), 2020 - 94 \\ Drajat Stiawan}

\section{PENDAHULUAN}

Sampai saat ini, matematika masih dianggap oleh sebagian siswa sebagai mata pelajaran yang sulit. Hal ini tidak lepas dari sifat matematika yang memang abstrak dan juga cara penyajiannya yang kurang variatif, serta kurangnya media untuk menyajikan hal yang abstrak menjadi hal yang konkret. Sebagai ilmu pengetahuan matematika memang mempunyai ciri yakni objek kajian yang abstrak, berpola deduktif, hierarkis dan tentu saja logis. Keabstrakan objek matemaika bisa diketahui dari objeknya yakni fakta, konsep, operasi dan prinsip (Soedjadi, 2000). Keabstarakan objek matematika tersebut yang menjadikan sebagian siswa enggan untuk mempelajari matematika dan faham dengan materi matematika, oleh karena itu dibutuhkan semacam "jembatan" sebagai penghubung antara keilmuan matematika yang abstarak tetap terpelihara kemurniannya tetapi disisi lain supaya mudah untuk difahami.

Disisi lain, cara guru dalam mengajar yang monoton dan tidak inovatif menjadi sebab kemalasan siswa mempelajari matematika. Hal ini terjadi karena diburu oleh target dalam pengajaran, sehingga guru cenderung menyampaikan ketercapaian konsep materi saja dan kurang memperdulikan pemahaman siswa. (Trianto, 2007) mengemukakan bahwa ada banyak kritik yang ditujukan pada bagaimana cara guru menyampaikan materi atau mengajar yang hanya fokus pada penguasaan sejumlah informasi atau konsep belaka. Materi atau konsep yang disampaikan pada peserta didik sangatlah penting akan tetapi bisa saja kurang memiliki makna/berarti bila konsep tersebut kurang bisa difahami oleh siswa tersebut.

Pembelajaran menurut (Rohani, 2006) merupakan sebuah proses interaksi antara siswa dengan guru dan sumber belajar pada suatu lingkungan belajar. Proses pembelajaran akan tercapai dengan baik dan maksimal jika terjadi kerjasama antara guru, siswa dan sumber belajar. Oleh karena itu kerjasama antara guru, siswa, dan sumber belajar ini sangat penting untuk meningkatkan mutu pembelajaran. Kerjasama tersebut bisa tercapai jika guru mampu mengelola pembelajaran dengan baik. akan terwujud jika terdapat pengelolaan pembelajaran yang baik. Disamping itu, keberhasilan proses pembelajaran juga tergantung pada adanya interaksi serta timbal balik antara guru dan siswa. Interaksi antara guru dan siswa bisa terwujud jika guru menerapkan strategi pembelajaran yang menyenangkan dan memahamkan ketika menyampaikan materi.

Strategi pembelajaran yang diterapkan oleh guru pada kegiatan belajar mengajar akan berpengaruh terhadap keberhasilan siswa. Sehingga penting bagi guru untuk merencanakan dan membuat stategi pelaksanaan pembelajaran menjadi menyenangkan dan variatif. Hal ini dapat berdampak positif bagi peserta didik karena dalam proses 


\section{Histogram: Jurnal Pendidikan Matematika, 4 (1), 2020 - 95 \\ Drajat Stiawan}

pembelajarannya tanpa adanya tekanan tapi menyenangkan tanpa mengurangi esensi dari materi yang diajarkan. Sebagaimana menurut (Sanjaya, 2010) bahwa strategi pembelajaran merupakan perencanaan dalam pembelajaran yang berisi rangkaian kegiatan yang didesain untuk mencapai pendidikan tertentu.

Pada umumnya sekolahan hanya memberi materi pembelajaran tanpa mengaitkan konsep tersebut dengan alam sekitar. Sehingga kegiatan pembelajaran cenderung membosankan dan kurang memberi pengalaman secara langsung pada siswa. Pembelajaran menjadi menyenangkan jika materi yang disajikan dikaitkan dengan kehidupan sehari-hari, serta dalam penyajian tidak hanya fokus didalam kelas tapi perlu untuk membawa keluar kelas dan berbaur dengan alam. Belajar dengan alam akan membawa siswa untuk lebih mencintai alam serta melatih belajar mandiri dan belajar untuk bekerja sama.

Konsep dalam Sekolah Alam yakni memadukan alam dan lingkungan sebagai sarana dan media untuk kegiatan pembelajaran. Melalui pembelajaran langsung dengan alam sebagai media pembelajaran akan menciptakan pembelajaran yang bermakna. Artinya bahwa siswa mampu memahami dan menemukan konsep melalui pengalaman secara langsung dan nyata. Dalam kegiatan pembelajaran di sekolah alam dituntut akan keaktifan dan keterlibatan siswa dalam proses belajar mengajar untuk memperoleh hasil maksimal. Hal ini juga menjadikan siswa akan terlibat aktif dalam membuat keputusan dalam kegiatan pembelajaran. Siswa akan memilki tidak hanya pengetahuan tapi kecakapan hidup. Kecakapan hidup ini sangat berarti bagi bekal bermasyarakat nantinya.

Ciri sekolah alam menurut pendapat (Rohinah, 2014) yakni siswa lebih banyak belajar di alam terbuka serta action learning merupakan metode pembelajaran yang lebih banyak digunakan hal ini bertujuan supaya siswa memperoleh pengetahuan yang lebih mendalam melalui pengalaman langsung.

Beberapa riset sebagai pembanding sekaligus sebagai acuan, yakni penelitian yang dilakukan oleh (Yulianti \& Sulitiwati, 2014), pada penelitian ini lebih menyoroti pada kurikulum sekolah alam dan kaitannya dengan pendidikan karakter. Riset yang mempunyai tujuan untuk mengetahui serta menggambarkan konsep kurukulum sekolah alam dan bagaimana implementasinya pada karakter siswa, diperoleh hasil bahwa kurikulum disekolah alam ini mengintegrasikan pelajaran umum dan agama berdasarkan kurikulum kemendikbud. Dari perpaduan kurikulum ini diperoleh konsep sekolah alam dengan tripel $\mathrm{R}$ yakni reasoning, reaserch dan religius. Sedangkan pendidikan karakter diterapkan pada kegiatan-kegiatan ektrakurikuler misal kegiatan pramuka, PMR dan lainnya. 


\section{Histogram: Jurnal Pendidikan Matematika, 4 (1), 2020 - 96 \\ Drajat Stiawan}

Selanjutnya penelitian yang dilakukan oleh (Mustafida, 2016) dikatakan bahwa proses belajar erat kaitannya dengan lingkungan dimana proses pembelajaran berlangsung. Suasana yang penuh kegembiraan berdampak pada minat dan antusias belajar peserta didik. Sebaliknya suasana yang menegangkan dan menjemukan akan membawa pada suasana belajar yang jauh dari harapan. Guru sebagai pihak yang paling bertanggung jawab dalam pengelolaan pembelajaran di kelas wajib menciptakan atmosfir pembelajaran yang nyaman, dan menyenangkan bagi anak, karena dengan iklim kelas yang nyaman dan menyenangkan (kondusif) dapat memudahkan mereka dalam mentrasformasi hubungan interpersonal sehingga menjadi suatu komunitas pembelajaran yang produktif dan saling menghargai, yang memungkinkan terjadinya interaksi pembelajaran yang efektif dalam membantu tumbuh kembang anak atau peserta didik. Bertolak dari hal tersebut, maka semakin baik iklim kelas yang dibangun, akan semakin baik pula kondisi pembelajarannya, karena hanya iklim kelas yang "kondusiflah" suasana pembelajaran yang tenang, nyaman, menyenangkan, dan penuh kebermaknaan dapat diwujudkan. Hal ini sebagaimana menurut (Rapti, 2012) bahwa iklim sekolah yang positif akan meningkatkan pengajaran yang efektif.

Pada penelitian (Hidayanti \& Prihatin 2016), dengan tujuan penelitan adalah untuk mendeskripsikan serta menganalisis perencanaan dan evaluasi kurikulum pada sekolah alam, didapat hasil bahwa kurikulum adalah hasil perpaduan kekhasan sekolah yang berbasis pada multiple intellegence yang mengutamakan ahlak yang terintegrasi dengan memakai prinsip spider web, (2) bentuk perencanaan kurikulum yakni rencana harian kerja dan silabus, (3) pembetukan karakter dan ahlak merupakan implementasi dari kurikulum yang ada, (4) evaluasi yang dilaksanakan secara kontinu yang berbrntuk mingguan maupun bulanan bahkan tahunan.

Berdasarkan paparan yang sudah disampaikan, peneliti tertarik melakukan penelitian tentang bagaimana strategi pembelajaran yang dilakukan pada sekolah yang menggunakan konsep alam khusunya diwilayah pekalongan. Strategi pembelajaran yang berbeda tentunya dengan sekolah konvensional pada umumnya. Sehingga memunculkan pertanyaan, yakni bagaimana strategi pembelajaran matematika yang dilaksakanan di sekolah alam?

\section{METODE PENELITIAN}

\section{A. Jenis Penelitian}

Penelitian ini merupakan penelitian deskriptif yang berjenis kualitatif. Menurut Nasution penelitian kualitatif pada hakekatnya adalah mengamati orang dalam 


\section{Histogram: Jurnal Pendidikan Matematika, 4 (1), 2020 - 97 \\ Drajat Stiawan}

lingkungan hidupnya, berinteraksi dengan mereka, berusaha memahami bahasa dan tafsiran mereka tentang dunia sekitarnya (Sugiyono, 2016). Penelitian ini berusaha untuk mendiskripsikan strategi pembelajaran matematika yang dilakukan oleh guru disekolah alam.

\section{B. Setting Penelitian}

1. Waktu dan Tempat Penelitian

Penelitian ini dilaksanakan pada bulan Mei sampai dengan Juli tahun 2019. Bertempat di sekolah alam Ma'had Islam Pekalongan.

\section{Subjek Penelitian}

Informan pada penelitian ini adalah kepala sekolah, guru matematika kelas IV dan V, serta beberapa siswa kelas IV dan V. Teknik analisis data menggunakan pendekatan kualitatif versi miles dan huberman (Sugiyono, 2016) dengan melalui empat tahapan yaitu pengumpulan data, reduksi data penyajian data dan pengambilan kesimpulan.

\section{Teknik Analisis Data}

Pengumpulan data melalui observasi dan wawancara. Wawancara dilaksanakan untuk mendapatkan data terkait kurikulum yang digunakan, serta untuk memperoleh data tentang strategi dan sistem evaluasi yang digunakan. Sedangkan observasi dilakukan untuk mendapat data bagaimana implementasi strategi pembelajaran dan penilaian yang digunakan. Teknik analisis data menggunakan pendekatan kualitatif versi miles dan huberman (Sugiyono 2016) dengan melalui empat tahapan yaitu pengumpulan data, reduksi data, penyajian data dan pengambilan kesimpulan.

Pengumpulan data dilakukan dengan wawancara dan observasi. Hasil wawancara dan hasil pengamatan ditelaah dan difahami dengan membaca berulangkali. Reduksi data diperoleh dengan memilah data yang komplek dari hasil wawancara dan hasil observasi dengan membuat rangkuman sehingga tidak keluar dari tujuan penelitian. Selanjutnya penyajian data dilakukan dengan membuat pola dan hubungan dari reduksi data sehingga mudah untuk difahami. Pengambilan kesimpulan berdasarkan dari data yang sudah di display sedemikian rupa.

\section{HASIL DAN PEMBAHASAN}

\section{A. Hasil Penelitian}

Melalui penelitian yang dilakukan diperoleh hasil sebagai berikut:

Kurikulum yang dilaksanakan dan sebagai pedoman pada sekolah alam Ma'had

Islam Pekalongan adalah mengikuti kurikulum pemerintah yakni menggunakan 


\section{Histogram: Jurnal Pendidikan Matematika, 4 (1), 2020 - 98 \\ Drajat Stiawan}

kurikulum 2013. Rencana pembelajaran di sekolah alam Ma'had Islam sudah menggunakan RPP. Penyusun RPP berdasarkan pada kompetensi inti dan mengikuti kalender yayasan. Untuk silabus guru membuat sendiri dengan menyesuaikan kurikulum dari dinas pendidikan.

Pembelajaran di sekolah alam Ma'had Islam untuk pelaksanaan ada sedikit perbedaan dengan sekolah pada umumnya yang hanya berlangsung di ruangan kelas (In door). Sekolah alam di SD Ma'had Islam untuk pelaksanaan pembelajaran selain di dalam kelas juga ada pembelajaran di luar kelas (out door), outbound, ada juga belajar di masjid dan berkunjung ke kantor atau tempat yang sesuai dengan Mata Pelajaran. Untuk mata pelajaran matematika, pelaksanaan pembelajaran masih sering dilakukan di ruang kelas, hanya saja penggunaan media pembelajarannya menggunakan bahan-bahan yang ada di alam, serta menyesuaikan dengan materi yang sedang diajarkan oleh guru.

Penilaian pembelajaran di sekolah alam Ma'had Islam pekalongan sama seperti di sekolah pada umumnya, yakni dengan memberikan tugas, berdasarkan keaktifan siswa, serta adanya Ulangan Tengah Semester, dan Ulangan Akhir Semester.

\section{B. Pembahasan}

1. Kurikulum di Sekolah Alam Ma'had Islam Pekalongan

Sebagaimana sekolah pada umumnya yang memiliki kurikulum, maka sekolah alam Ma'had Islam juga mempunyai kurikulum. Kurikulum yang digunakan pada sekolah alam Ma'had Islam Pekalongan sejak tahun 2019 semuanya menggunakan kurikulum 13. Kurikulum ini berlaku untuk kelas satu sampai kelas enam. Hal ini mengikuti aturan dari pemerintah untuk menggunakan kurikulum 13.

2. Model Pembelajaran Matematika di Sekolah Alam Ma'had Islam Pekalongan

Sekolah alam merupakan sekolah yang salah satu dalam kegiatan pembelajarannya menggunakan media alam sekitar. Serta dalam proses pembelajaranya tidak hanya didalam kelas melainkan juga di luar kelas (outdoor). Sesuai dengan pendapat (Virrayani \& Sulistijowati, 2014) bahwa kegiatan pembelajaran disekolah alam terbagi menjadi dua yakni kegiatan didalam ruangan dan kegiatan diluar ruangan. Kegiatan yang dilakukan diluar ruangan tidak berbeda dengan kegiatan didalam ruangan, keduanya merupakan kegiatan yang saling mendukung. Hal ini berbeda dengan sekolahan pada umumnya, dimana kegiatan pembelajaran sebagian besar waktu digunakan di dalam kelas.

Kegiatan pembelajaran yang dilaksanakan di luar kelas yakni dengan memanfaatkan lingkungan alam sekitar sebagai media sekaligus bahan pembelajaran 


\section{Histogram: Jurnal Pendidikan Matematika, 4 (1), 2020 - 99 \\ Drajat Stiawan}

siswa. Metode pembelajaran lebih banyak menggunakan aktif learning, dimana dengan metode ini para siswa bisa aktif menggunakan media lingkungan sebagai bahan pembelajaran, sehingga siswa akan mendapat pengalaman secara langsung. Seringkali Guru dalam memberikan materi pembelajaran tanpa peduli terhadap karakteristik dan suasana para siswanya, padahal pembelajaran yang menarik dan menyenangkan tidak hanya pemberian materi saja, tetapi lebih dari itu yakni mengajak siswa untuk ikut merencanakan bahkan mengekplorasi kemampuan dalam diri terutama belajar dari alam (Mufidah, 2015)

Selain itu, prinsip pembelajaran Learning by doing selalu ditekankan pada model pembelajaran di SD Alam Ma'had Islam Pekalongan. Melalui prinsip ini maka pemahaman siswa akan lebih tertanam dan mendalam serta bertahan lama. Sehingga tidak hanya memahami teori akan tetapi mengalami atau belajar langsung dengan alam sekitar.

Secara garis besar pendidikan di Sekolah Dasar Alam Ma'had Islam Pekalongan memiliki tiga fungsi utama yakni:

a. Alam sebagai wahana belajar

Sekolah Dasar Ma'had Islam Pekalongan merancang kegiatan pembelajaran interaktif tidak hanya di dalam kelas yang dibatasi oleh dinding-dinding kelas, akan tetapi melibatkan alam sekitar sekolah sebagai wahana untuk belajar. Sehingga Di Sekolah Dasar Alam Ma'had Islam Pekalongan, para siswa belajar dimana saja tapi masih dalam lingkup lingkungan sekolah.

b. Alam sebagai piranti pembelajaran

Media dan bahan ajar bisa didapatkan dari mana saja termasuk dari alam sekitar. Sehingga pemanfaatan alam sekitar tentu mendukung apa yang diperlukan pada kegiatan pembelajaran, serta semakin variatif dan mendalam dalam pemahaman materi. Untuk menambah pemahaman siswa, maka guru juga manggunakan alam sekitar sebagai piranti dalam kegiatan pembelajaran.

c. Alam sebagai entitas pembelajaran

Kegiatan pembelajaran dilakukan dengan pengamatan terhadap gejala-gejala alam yang berhubungan dengan materi pembelajaran. Sehingga mampu untuk mengasah daya fikir dan daya kritis serta kepekaan anak. Maka alam berfungsi sebagai entitas atau objek dalam proses pembelajaran.

Sejak awal berdirinya Sekolah Dasar Alam Ma'had Islam Pekalongan telah memadukan keislaman dan kurikulum nasional sehingga menjadi kurikulum Islam terpadu dalam hal ini adalah kurukulum 13, artinya tidak terjadi pemisahan materi 


\section{Histogram: Jurnal Pendidikan Matematika, 4 (1), 2020 - 100 Drajat Stiawan}

agama dan umum. Terkait kegiatan pembelajaran yang dilaksanakan di SD Alam Ma'had Islam Pekalongan tidak hanya mengedepankan rutinitas dikelas, tetapi lebih pada tujuan yang lebih komprehensif yakni terkait pengembangan akhlak yang mulia, peningkatan daya fikir dan nalar, mengasah jiwa kepemimpinan melalui kegiatan outbond serta pengembangan jiwa mandiri melalui kegiatan wirausaha.

\section{Strategi Pembelajaran Matematika Sekolah Alam}

Guru dalam pembelajaran selayaknya panglima perang yang mahir strategi berperang, semua strategi dilaksanakan dalam rangka untuk memenangkan pertempuran. Dalam hal ini, strategi yang dilakuakan guru dalam rangka tercapainya tujuan pembelajaran. Tujuan pembelajaran tersebut diperoleh dengan cara yang nyaman serta menyenangkan dengan kualitas pembelajaran yang baik (Barlian, 2013).

Beberapa metode yang dipraktekan dan efektif bagi pembelajaran matematika di Sekolah Dasar Alam Ma'had Islam, antara lain: metode ceramah, metode tanya jawab, metode pemberian tugas dan metode bermain. Metode bermain merupakan metode yang efektif diterapkan pada kegiatan pembelajaran diluar kelas, hal ini karena anak yang secara psikologi masih senang bermain. Bahkan bermain merupakan kebutuhan pokok pada anak. Dengan memadukan kegiatan bermain ini untuk kegiatan pembelajaran, maka secara tidak langsung telah mengembangkan daya motorik dan kreatifitas anak bahkan kognitifnya. Pada SD Alam Ma'had Islam Pekalongan model bermain sekaligus juga digunakan untuk bermain yang mengandung unsur-unsur keagamaan. Strategi dalam pembelajaran yang dilaksanakan dengan menggabungkan berbagai metode pembelajaran. Sehingga kegiatan pembelajaran tidak monoton, tidak garing dan membuat antusias siswa untuk belajar. Dan metode pembelajaran yang dipilih disini tentu saja lebih menekankan pada keaktifan siswa.

\section{Pelaksanaan Pembelajaran Matematika Sekolah Alam}

Pelaksanaan pembelajaran diawali dengan persiapan guru melakukan perencanaan pembelajaran dengan membuat Rencana Pelaksanaan Pembelajaran (RPP). RPP dibikin oleh masing-masing guru dengan acuan pada kurikulum nasional.

Pada prakteknya, ketika proses pembelajaran dikelas, guru menggunakan berbagai metode pengajaran, agar kefokusan siswa senantiasa terjaga. Untuk menghindari kebosanan, guru juga memutarkan video pembelajaran sesuai dengan materi yang diajarkan. Disamping itu, karena berkonsep alam, maka pembelajaran juga dilaksanakan dialam terbuka. Sehingga anak-anak bisa belajar sambil bermain, karena 


\section{Histogram: Jurnal Pendidikan Matematika, 4 (1), 2020 - 101 \\ Drajat Stiawan}

memang dunia anak adalah dunia bermain. Jadi bermain disini tidak hanya sekedar bermain, tetapi bermain sambil belajar.

Pembelajaran disekolah alam ini juga tidak hanya memberikan materi, tetapi juga ada pembiasaan keagamaan yang dilakukan yaitu dengan berdoa ketika memulai pembelajaran dan setelah selesai pembelajaran.

\section{Evaluasi}

Model penilaian yang dilakukan oleh guru di SD Alam Ma'had Islam Pekalongan menggunkan teknik evaluasi tertulis, serta dikerjakan secara individu. Evaluasi tersebut berupa ulangan harian, kuiz, ulangan tengah semester dan langan akhir semester. Ulangan harian dilakukan untuk mengetahui pemahaman siswa setelah menerima materi. Untuk kuiz dilaksanakan secara insidental tidak terpaku pada waktu, dan tanpa pemberitahuan sebelumnya. Hal ini bertujuan supaya siswa tetap menjaga belajarnya sehingga selalu siap kapan saja dilaksanakan kuiz. Untuk ulangan tengah semester dilaksanakan pada pertengahan semester sedangkan ulangan akhir semester merupakan evaluasi yang dilakukan di setiap akhir semester.

Adanya pemberian kuiz untuk mengetahui sejauhmana para siswa mampu memahami materi yang disampaikan. Selain itu juga mengurangi model pemberian pekerjaan rumah (PR), karena dianggap kurang efektif untuk mengetahui pemahaman siswa. Karena guru tidak bisa secara langsung untuk mengetahui apakah soal yang diberikan untuk pekerjaan rumah merupakan jawaban sendiri atau justru mendapatkan bantuan dari orang tua atau keluarga. Sedangkan jika diberi evaluasi secara langsung dikelas maka akan mempermudah untuk mengetahui siswa sudah paham atau belum terkait materi yang diberikan.

Pemberlakuan reward juga diterapkan dalam pelaksanaan evaluasi, misalkan ada siswa yang mampu menjawab pertanyaan guru dengan benar maka akan diberi hadiah bisa berupa buku, ballpoint dan lainnya. Sedangkan untuk siswa yang berhasil menjadi rangking terbaik akan diberi uang pembinaan. Hal ini bertujuan untuk menambah motivasi siswa dalam belajar khususnya materi matematika.

\section{PENUTUP}

\section{A. Kesimpulan}

Berdasarkan penelitian yang telah dilakukan, dapat diambil kesimpulan bahwa, strategi belajar yang diterapkan guru ketika melaksanakan pembelajaran matematika didalam kelas menggunakan metode ceramah, tanyajawab dan pemberian tugas. 


\section{Histogram: Jurnal Pendidikan Matematika, 4 (1), 2020 - 102 Drajat Stiawan}

Sedangkan kegiatan pembelajaran diluar kelas lebih banyak mengguanakan metode bermain. Dengan strategi pembelajaran sesuai dengan kondisi peserta didik, tentunya dapat menghasilkan pembelajaran yang maksimal dan menyenangkan. Dengan pemahaman ini, guru dapat menentukan strategi yang cocok yang sesuai dengan bentuk materi, mungkin saja berupa konsep, fakta, dalil atau rumus.

Beberapa kendala yang ditemui pada kegiatan pembelajaran matematika sekolah alam adalah adanya kebisingan yang terjadi selama kegiatan pembelajaran berlangsung, hal ini terjadi karena sekolahan masih berada tidak jauh dari pusat keramaian.

\section{B. Saran}

Penelitian ini dapat dijadikan masukan untuk guru sebagai alternatif dalam menentukan strategi belajar matematika khususnya pada sekolahan yang berbasis alam. Sehingga mampu merubah persepsi siswa yang semula menganggap matematika merupakan matapelajaran membosankan menjadi mata pelajaran yang mengasyikan. Dalam pembelajaran perlu memperbanyak strategi yang digunakan supaya siswa semangat dan termotivasi untuk mengikuti pelajaran. Strategi pembelajaran yang berbasis permainan sangat pas diterapkan untuk siswa pada tataran sekolah dasar dan pada sekolah yang berbasis alam.

\section{DAFTAR PUSTAKA}

Barlian, I. (2013). Begitu Pentingkah Strategi Belajar Mengajar Bagi Guru?. Jurnal Forum Sosial, 6(1), 241 - 246.

Mufidah, H. (2015). Sistem Pembelajaran Matematika Di Sekolah Alam. Jurnal Ummul Quro, VI(2), 36 - 47.

Mustafida, F. (2016). Strategi Menciptakan Iklim Kondusif Di SD/MI (Sebuah Kajian Pedagogis Dan Psikologis). Madrasah: Jurnal Pendidikan dan Pembelajaran Dasar, 8(2), 64 - 76.

Hidayati, I, F \& Prihatin, T. (2016). Pengelolaan Kurikulum Sekolah Alam Di TK Alam Al Biruni Cirebon. Indonesian Journal of Curriculum and Educational Technology Studies IJCETS, 4(1), 32 - 39.

Rapti, D. (2012). School Climate as an Important Component in School Effectiveness ÖNEMLİ. Academicus Internasional Scientific Journal. MMXII(8), 110 - 125.

Rohani. (2006). Pengelolaan Pembelajaran. Jakarta: Rineka Cipta.

Rohinah. (2014). Sekolah Alam: Paradigma Baru Pendidikan Islam Humanis. Nadwa, $8(2), 282-294$.

Sanjaya, W. (2010). Strategi Pembelajaran Berorientasi Standar Proses Pendidikan. 


\section{Histogram: Jurnal Pendidikan Matematika, 4 (1), 2020 - 103 \\ Drajat Stiawan}

Jakarta: Prenanda Media Group.

Soedjadi, R. (2000). Kiat Pendidikan Matematika Di Indonesia: Konstatasi Keadaan Masa Kini Menuju Harapan Masa Depan. Bandung. Direktorat Jenderal Pendidikan Tinggi: Diknas

Sugiyono. (2016). Metodologi Penelitian Kuantitatif, Kualitatif, Dan R\&D. Bandung: Alfabeta

Trianto. (2007). Model-Model Pembelajaran Inovatif berorientasi kontruktivistik. Jakarta: Prestasi Pustaka.

Virrayani, A, N \& Sulistijowati, M. (2014). Perancangan Sekolah Alam Di Kecamatan Kenjeran, Surabaya. Jurnal Sains Dan Seni Pomits, 2(1), 1 - 5.

Yulianti, \& Sulistyowati, P. (2014). Kajian Kurikulum Sekolah Alam Dalam Rangka Mewujudkan Pendidikan Karakter Siswa Tingkat Sekolah Dasar. JP2SD: Jurnal Pemikiran Dan Pengembangan SD, 1(4), 288 - 291. 